\title{
Antioxidant Activity of Methoxylated Flavonoids in Oils in Deep Frying Processes
}

\author{
Onesmus Maina Wanjau ${ }^{1 *}$, Symon Maina Mahungu ${ }^{2}$, Josphat Clement Matasyoh ${ }^{1}$ \\ ${ }^{1}$ Department of Chemistry, Faculty of Science, Egerton University, Nakuru, Kenya \\ ${ }^{2}$ Deparment of Dairy and Food Science, Faculty of Agriculture, Egerton University, Nakuru, Kenya \\ Email: *owanjau@egerton.ac.ke
}

How to cite this paper: Wanjau, O.M., Mahungu, S.M. and Matasyoh, J.C. (2018) Antioxidant Activity of Methoxylated Flavonoids in Oils in Deep Frying Processes. Food and Nutrition Sciences, 9, 1273-1284. https://doi.org/10.4236/fns.2018.911091

Received: August 30, 2018

Accepted: November 9, 2018

Published: November 12, 2018

Copyright (c) 2018 by authors and Scientific Research Publishing Inc. This work is licensed under the Creative Commons Attribution International License (CC BY 4.0).

http://creativecommons.org/licenses/by/4.0/

(c) (i) Open Access

\begin{abstract}
Methoxylated flavonoids isolated from cold acetone leaf wash of Polygonum senegalense, 5-hydroxy-7-methoxyflavanone 1 and 5-hydroxy-6,7-dimethoxyflavanone 3 , were tested for their ability to enhance thermal stability of vegetable oils. Determination of the peroxide value (P.V.) and the $p$-Anisidine value ( $p$-A.V.) was done according to the standard methods of analysis. The compounds were tested for in vitro cytotoxicity against a mammalian cell-line, Chinese Hamster Ovarian (CHO) using the 3-(4,5-dimethylthiazole2-yl)-2,5-diphenyltetrazoliumbromide (MTT)-assay. Studies on changes in peroxide and $p$-Anisidine values for the oils heated to temperatures between $180^{\circ} \mathrm{C}$ and $200^{\circ} \mathrm{C}$ recorded better stability enhancement at $100 \mathrm{ppm}$ concentration with these flavonoids than the commercial antioxidant, butylated hydroxytoluene (BHT). The plant-based flavonoids had no significant cytotoxic effect against the $\mathrm{CHO}$ cell-line and may serve as alternative antioxidants to synthetic ones which have previously raised great concern over the health of consumers.
\end{abstract}

\section{Keywords}

Polygonum senegalense, Antioxidant Activity, Methoxylated Flavonoids, Vegetable Oils, Cytotoxic Effect

\section{Introduction}

Stability enhancement of fish oil is necessary to improve its shelf-life because fish oil contains highly unsaturated oils which are more susceptible to oxidation [1]. The rate and extent of formation of oxidation products in oils depends on the nature of the fatty acid composition (monounsaturated or polyunsaturated), the temperature at which the oil is heated [2] and the presence of metal ions [3] 


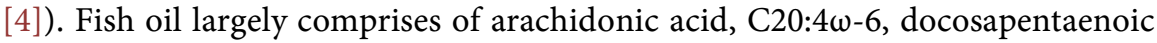

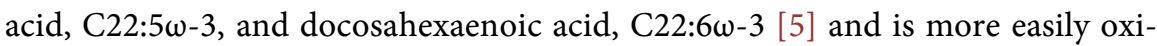
dized than vegetable oil [6]. Lipid oxidation is a highly deteriorative process and health disorders such as atherosclerosis and cancerogenesis among others correlate highly to the consumption of highly oxidized oils [7].

Edible fats/oils may contain up to $200 \mathrm{ppm}$ of synthetic antioxidants, such as butylated hydroxyanisole (BHA) and butylated hydroxytoluene (BHT) [8], purposely added to improve the shelf life of the edible fats/oils. The use of synthetic antioxidants is, however limited, because of their physical characteristics and the unfolding toxicological concerns on some of the synthetic antioxidants [9].

Flavonoid aglycones are reported to be deposited on the surface of leaves, twigs and seeds of Polygonum senegalense and Psiadia punctulata, with a higher deposition on younger plant parts than on the older parts [10] [11]). The existence of an exudate on the leaf surface, rich in methoxylated flavonoids [12] [13]), is fascinating. The constituent compounds of leaf surface exudates [14] supposedly serve some protective role on the plant [15]). Epicuticular layer and external flavonoids not only reflect radiation, but are also known to be good quenchers of singlet oxygen [16]. Some of the constituent compounds of the leaf surface exudates are relatively non-polar and could perhaps be endowed with invaluable bioactivity in the relatively non-polar fish oil and edible oils. The choice for an oil stability enhancer must critically address the solubility and thermal stability of the oil additive and evaluate their cytotoxicity levels.

The presence of some synthetic antioxidants in fats and oils may not guarantee stability at deep frying temperatures. Antioxidants of low boiling point may gradually vaporize and thus expose the oil to oxidation [17]. The oil may degenerate into various oxidation products, some of which may have injurious effects to the body. Antioxidant principles, stable at high temperatures, must be identified for use as oil additives to fortify the heat stability of the oils. The concentration levels of antioxidants may continue to diminish through vaporization at the high temperatures, leaving the oil exposed to further oxidation [18].

\section{Materials and Methods}

\subsection{Plant Materials}

The resinous leafy branches of $P$. senegalense were harvested, along the river banks of Njoro river within Egerton University, Nakuru County, Kenya, at an altitude of $2300 \mathrm{~m}$, twenty five kilometers, west of Nakuru town. A voucher specimen is deposited in the National Museum of Kenya Herbarium.

\subsection{Extraction}

One kilogram of leaves detached from the branches of $P$. senegalense plant were stuffed into a $5 \mathrm{~L}$ erlmeyer flask for extraction. A 1.5 liter portion of acetone was introduced into the flask and shaken for two minutes and decanted as an orange solution [19] two more fresh portions of acetone were used to wash the leaves 
clear of the orange exudate. The acetone extract was decanted and filtered through a filter paper into a $2.5 \mathrm{~L}$ brown glass bottle. The acetone was recovered using a rotary evaporator at a rotate speed of 100 , heated at a water bath regulated at $60^{\circ} \mathrm{C}$. The concentrate was preserved in an open brown glass bottle $(100$ $\mathrm{ml}$ ) and stored in a vacuum desiccator until it gave a constant mass of $47.5 \mathrm{~g}$ (i.e. $20.2 \%$ of dry leaves) on weighing.

\subsection{Chromatographic Methods}

$20 \mathrm{~g}$ of the extract was introduced into a glass column ( $4 \mathrm{~cm}$ diameter), packed with $129 \mathrm{~g}$ of 230 - 400 mesh silica gel. The column was sequentially eluted with $500 \mathrm{ml}$ portions of hexane, $40 \% \mathrm{CH}_{2} \mathrm{Cl}_{2}$ in hexane and finally with $60 \% \mathrm{CH}_{2} \mathrm{Cl}_{2}$ in hexane, effectively eluting four coloured bands ranging from yellow to red. The eluant was collected as $40 \mathrm{ml}$ fractions from which pure compounds were isolated through fractional crystallization from dichloromethane-methanol mixtures. Melting points (uncorrected), were determined using a Gallen camp melting point apparatus. ${ }^{1} \mathrm{H}$ and ${ }^{13} \mathrm{C}$ NMR spectra were determined at 500 and $125 \mathrm{MHZ}$, respectively.

Identification of the compounds was achieved through correlation of spectral data, melting point values and comparison with literature data [20].

\subsection{Determination of Peroxide and $p$-Anisidine Values}

Sunflower and rapeseed oils and fractionated palm shortening (Rina oil and Chipsy fat and Canola oil) were procured locally from local market in Nakuru. Two aluminium based cooking pots $(15 \mathrm{~cm}$ in diameter each) were used for electrically heating the oil in pot A and B (control) respectively.

$250 \mathrm{~g}$ of each oil sample was electrically heated in the cooking pots up to a temperature of $180^{\circ} \mathrm{C}-200^{\circ} \mathrm{C}$ for $7 \mathrm{hrs}$ each day. $50 \mathrm{mg}$ of the plant isolates were dissolved in $1 \mathrm{ml}$ of acetone in a vial bottle and introduced into the oil in pot A. The vial bottle was rinsed twice with $1 \mathrm{ml}$ portions of acetone and the washings transferred into the oil. The second pot served as a control into which $3 \mathrm{ml}$ of acetone was added into the oil. Determination of the peroxide value (P.V.) and the $p$-Anisidine value ( $p$-A.V.) was done according to the standard methods of analysis [21]. The experiment was repeated three times for each case.

\subsection{Cytotoxicity Screening Tests}

Compounds were tested for in vitro cytotoxicity against a mammalian cell-line, Chinese Hamster Ovarian (CHO) using the 3-(4,5-dimethylthiazole-2-yl)-2,5diphenyltetrazoliumbromide (MTT)-assay [22]. All samples were tested in triplicate on a single occasion. The MTT-assay is used as a calorimetric assay for cellular growth and survival, and compares well with other available assays [23] [24]). The tetrazolium salt MTT was used to measure all growth and chemosensitivity. Flavanone 1 (Polsen 1) was dissolved in 10\% methanol while flavanone 3 (polsen 3) was dissolved in 10\% DMSO. Compounds were tested as a suspension 
due to poor solubility. The initial concentration of the stock solutions was 2 $\mathrm{mg} / \mathrm{ml}$ for all samples. All compounds were stored at $-20^{\circ} \mathrm{C}$ until testing. Ementine was used as the positive control in all experiments. The initial concentration of all samples were $100 \mathrm{mg} / \mathrm{ml}$, which was serially diluted in complete medium with 10 -fold dilutions to give 6 concentrations, the lowest being, $0.001 \mu \mathrm{g} / \mathrm{ml}$. The $50 \%$ inhibitory concentration $\left(\mathrm{IC}_{50}\right)$ values for these samples were obtained from dose response curves, using a non-linear dose response curve fitting analyses via GraphPad Prism v, 4.0 software.

\section{Results and Discussion}

Column chromatography of the acetone leaf extract using dichlomethanehexane solvent system mixtures yielded known methoxylated flavonoids 1 and 3 (Figure 1). ${ }^{1} \mathrm{H}$ NMR and ${ }^{13} \mathrm{C}$ NMR spectra are shown on Figures 2-5.

5-Hydroxy-7-methoxyflavanone $\underline{1}$ was obtained as colourless crystalline flakes, melting point of $101^{\circ} \mathrm{C}$. The ${ }^{1} \mathrm{H}$ NMR spectrum of $\underline{1}$ showed the presence of one methoxyl group at $\delta$ 3.79. It also exhibited three sets of double doublets of an AMX system at $\delta 5.408(1 \mathrm{H}, \mathrm{J}=3.0,10.1 \mathrm{~Hz}), \delta 3.074(1 \mathrm{H}, \mathrm{J}=13.0,4.17 \mathrm{~Hz})$ and $\delta 2.81(1 \mathrm{H}, \mathrm{J}=3.17,14.08 \mathrm{~Hz})$ which were characteristic of $\mathrm{H}-2, \mathrm{H}-3_{\mathrm{ax}}$ and $\mathrm{H}-3_{\text {eq }}$, respectively, of the ring $\mathrm{C}$ of a flavanone moety (Rao et al., 2004). Two meta-coupled doublets, at $\delta 6.05$ and $6.06(\mathrm{~J}=2.38 \mathrm{~Hz})$, each integrating for one proton, were assigned to $\mathrm{H}-6$ and $\mathrm{H}-8$, respectively. Noesy correlation of the methoxy group signal to these protons and $\mathrm{HMBC}$ correlations assigned the methoxy group to $\mathrm{C}-7\left(\delta_{\mathrm{C}}\right.$ 167.98). A $\mathrm{D}_{2} \mathrm{O}$ exchangeable downfield signal at $\delta$ $12.01(\mathrm{IH})$ was assigned to a hydrogen-bonded hydroxyl group at C-5 $\left(\delta_{\mathrm{C}} 164\right)$ [25].

5-Hydroxy-6,7-dimethoxyflavanone $\underline{3}$ was obtained as light yellow crystals $(61.9 \mathrm{mg})$, melting point $147^{\circ} \mathrm{C}-148^{\circ} \mathrm{C}$. The flavanone nucleus was confirmed by the presence in the NMR spectrum of an ABX system centered at $\delta 2.81,3.08$ and 5.40 for the C-2 and C-3 protons. Signals at $\delta 3.83(3 \mathrm{H})$ and $3.86(3 \mathrm{H})$ were assigned to a hydrogen bonded $\mathrm{OH}$ for $\mathrm{C}-5, \delta_{\mathrm{C}}$ 155.0. $\mathrm{HMBC}$ correlations of the signal at $\delta_{\mathrm{H}} 11.85$ with one of the methoxylated $\mathrm{C}$-atoms $\left(\delta_{\mathrm{C}} 130.6\right)$ required the signal at $\delta_{\mathrm{H}} 6.11$ to be attached to C-8. A multiplet centered at $\delta_{\mathrm{H}} 7.41(5 \mathrm{H})$ was attributed to a mono-substituted ring C. Flavanones $\underline{1}$ and $\underline{\mathbf{3}}$ have previously been isolated from Onychium ciliculosum, a medicinal herb [26].

Four brands of vegetable oils; Sunflower oil, Canola oil, Rina oil and Chipsy fat when heated to $180^{\circ} \mathrm{C}-200^{\circ} \mathrm{C}$ displayed heat instability on assessment of

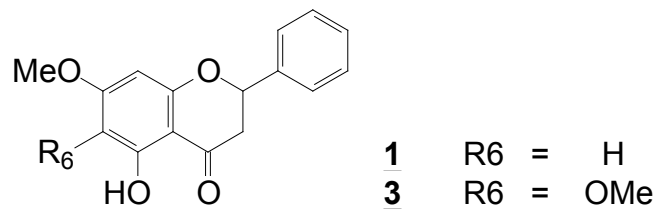

Figure 1. Flavanones $1 \& 3$. 


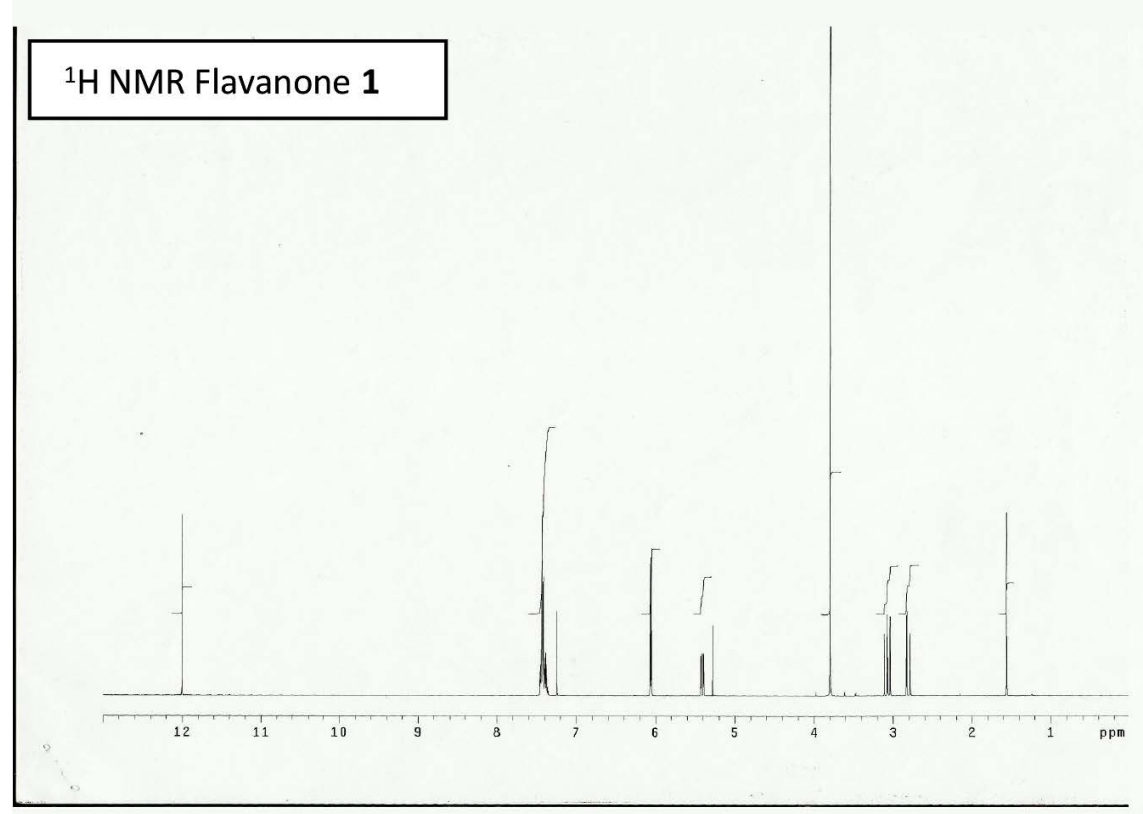

$\begin{array}{crlr}\text { INDEX } & \text { FREQUENCY } & \text { PPM } & \text { HEIGHT } \\ 1 & 4801.665 & 12.006 & 34.0 \\ 2 & 4801.268 & 12.005 & 43.8 \\ 3 & 2980.671 & 7.453 & 7.5 \\ 4 & 2974.125 & 7.436 & 43.8 \\ 5 & 2973.133 & 7.434 & 40.2 \\ 6 & 2966.785 & 7.418 & 28.9 \\ 7 & 2964.603 & 7.413 & 6.7 \\ 8 & 2961.032 & 7.404 & 6.2 \\ 9 & 2959.446 & 7.400 & 9.1 \\ 10 & 2959.049 & 7.399 & 9.1 \\ 11 & 2956.668 & 7.393 & 7.7 \\ 12 & 2954.486 & 7.387 & 10.4 \\ 13 & 2951.908 & 7.381 & 6.5 \\ 14 & 2948.734 & 7.373 & 6.2 \\ 15 & 2947.940 & 7.371 & 7.5 \\ 16 & 2895.969 & 7.241 & 16.8 \\ 17 & 2895.572 & 7.240 & 20.6 \\ 18 & 2426.239 & 6.066 & 15.4 \\ 19 & 2423.859 & 6.061 & 33.6 \\ 20 & 2420.288 & 6.052 & 35.8 \\ 21 & 2417.908 & 6.046 & 16.1 \\ 22 & 2170.745 & 5.428 & 9.6 \\ 23 & 2167.769 & 5.420 & 10.2 \\ 24 & 2157.653 & 5.395 & 10.3 \\ 25 & 2154.677 & 5.387 & 10.0 \\ 26 & 2111.434 & 5.279 & 12.1 \\ 27 & 2111.037 & 5.278 & 17.3 \\ 28 & 1517.329 & 3.794 & 200.0 \\ 29 & 1244.379 & 3.111 & 15.1 \\ 30 & 1231.287 & 3.079 & 14.4 \\ 31 & 1227.121 & 3.068 & 19.9 \\ 32 & 1214.227 & 3.036 & 19.5 \\ 33 & 1132.897 & 2.833 & 19.7 \\ 34 & 1129.724 & 2.825 & 20.8 \\ 35 & 1115.640 & 2.790 & 15.4 \\ 36 & 1112.466 & 2.782 & 14.5 \\ 37 & 625.280 & 1.563 & 26.6 \\ 38 & 624.487 & 1.561 & 44.5 \\ 39 & 623.495 & 1.559 & 14.4\end{array}$

Figure 2. ${ }^{1} \mathrm{H}$ NMR spectrum.

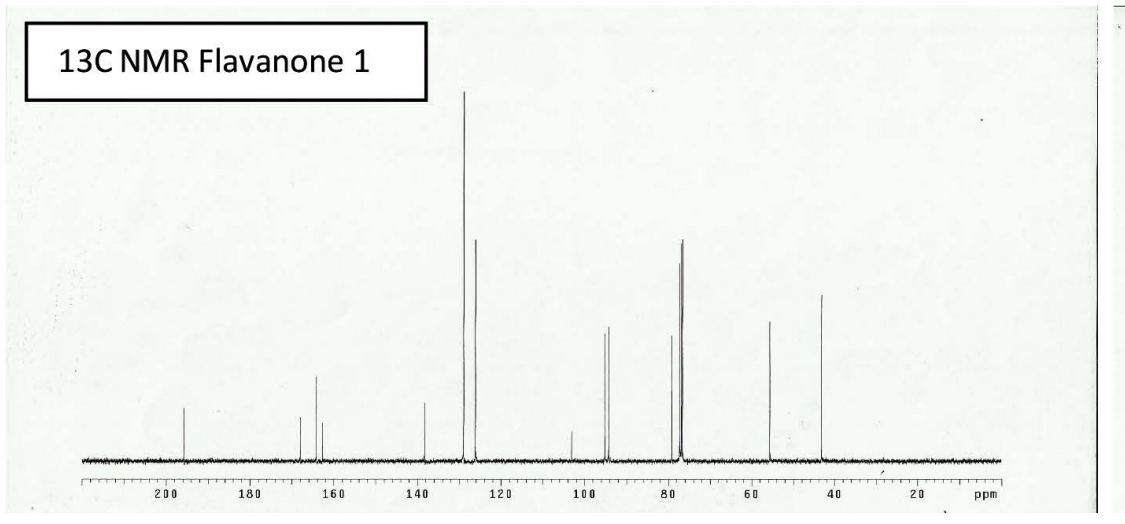

\begin{tabular}{|crlr|}
\hline & & & \\
INDEX & FREQUENCY & PPM & \multicolumn{1}{l|}{ HEIGHT } \\
1 & 19688.072 & 195.774 & 14.4 \\
2 & 16893.100 & 167.982 & 11.9 \\
3 & 16505.825 & 164.131 & 23.0 \\
4 & 16369.043 & 162.770 & 10.5 \\
5 & 13912.730 & 138.345 & 15.8 \\
6 & 12960.198 & 128.874 & 100.0 \\
7 & 12683.338 & 126.121 & 59.8 \\
8 & 10371.224 & 103.129 & 8.0 \\
9 & 9566.186 & 95.124 & 34.5 \\
10 & 9478.843 & 94.256 & 36.4 \\
11 & 7966.822 & 79.220 & 34.1 \\
12 & 7775.657 & 77.320 & 53.4 \\
13 & 7743.521 & 77.000 & 58.9 \\
14 & 7711.386 & 76.680 & 60.0 \\
15 & 5600.325 & 55.688 & 37.7 \\
16 & 4361.868 & 43.374 & 45.0 \\
& & & \\
& & &
\end{tabular}

Figure $3 .{ }^{13} \mathrm{C}$ NMR spectrum.

their patterns in both the $p$-anisidine and the peroxide values as observed in Figure 6 and Figure 7.

Stability enhancement for these oils was implied based on the continued rise in peroxide and $\mathrm{p}$-anisidine values for 14 hours on average when flavanones isolated from the $P$. senegalense were introduced into the oils at concentrations of $100 \mathrm{ppm}$ as observed in Figures 8-11.

5-Hydroxy-7-methoxyflavanone suppressed the rise in p-Anisidine values and the peroxide values respectively and resulted in predictable patterns for all the oils as observed in Figures 8-11. It also prevented oil browning and registered a delay in rise in peroxide values, recording a maximum after 14 hours on average. 5-Hydroxy-6,7-dimethoxyflavanone $\underline{\mathbf{3}}$ also displayed similar stability enhancement patterns when introduced into Sunflower oil at a concentration of $100 \mathrm{ppm}$. 


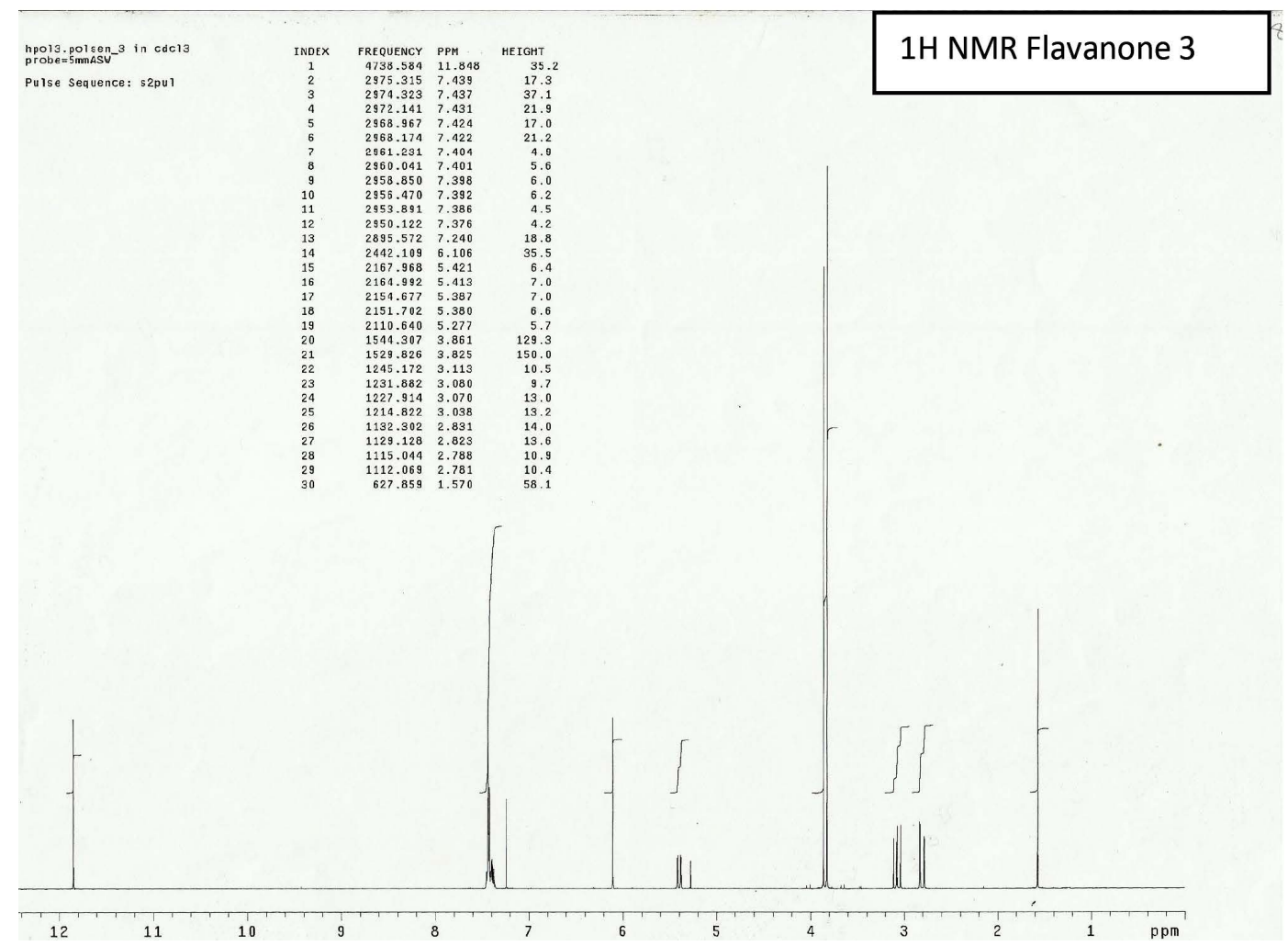

Figure 4. 1H NMR Spectrum.

\begin{tabular}{|c|c|c|c|c|}
\hline 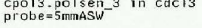 & INDEX & FREQUENCY & PPM & НЕТGHT \\
\hline \multirow[t]{14}{*}{ Pulse Sequence: s2pul } & 2 & 16183.645 & $\begin{array}{l}160.927 \\
160\end{array}$ & \\
\hline & 4 & $\begin{array}{l}15955.400 \\
15587.901\end{array}$ & $\begin{array}{l}158.657 \\
155.003\end{array}$ & 3 \\
\hline & 4 & 13902.842 & 138.247 & 13.8 \\
\hline & 6 & 13129.940 & 130.561 & \\
\hline & ? & 12968.438 & 128.956 & \\
\hline & 8 & 12962.670 & 128.898 & \\
\hline & ${ }^{9}$ & 12683.333 & 126.121 & 68.5 \\
\hline & $\begin{array}{l}10 \\
11\end{array}$ & $\begin{array}{r}10376.168 \\
9218.462\end{array}$ & $\begin{array}{l}103.178 \\
91.667\end{array}$ & $\begin{array}{l}12.6 \\
30.4\end{array}$ \\
\hline & 12 & 7999.782 & 79.548 & \\
\hline & 13 & 7775.657 & 77.320 & \\
\hline & 14 & 7743.521 & 77.000 & 70.0 \\
\hline & 15 & 7711.386 & 76.680 & 66.7 \\
\hline & $\begin{array}{l}16 \\
17\end{array}$ & $\begin{array}{l}5125.206 \\
5650.588\end{array}$ & $\begin{array}{l}60.908 \\
56.188\end{array}$ & $\begin{array}{l}25.7 \\
27.8\end{array}$ \\
\hline & 18 & 4363.516 & 43.390 & 35,5 \\
\hline
\end{tabular}

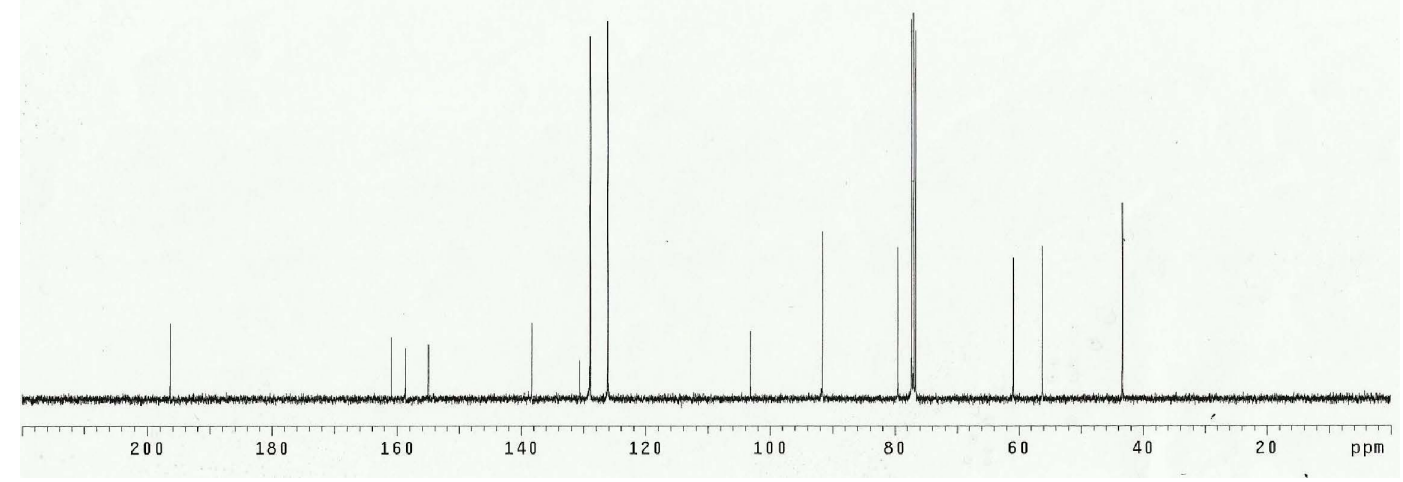

Figure $5 .{ }^{13} \mathrm{C}$ NMR Spectrum. 


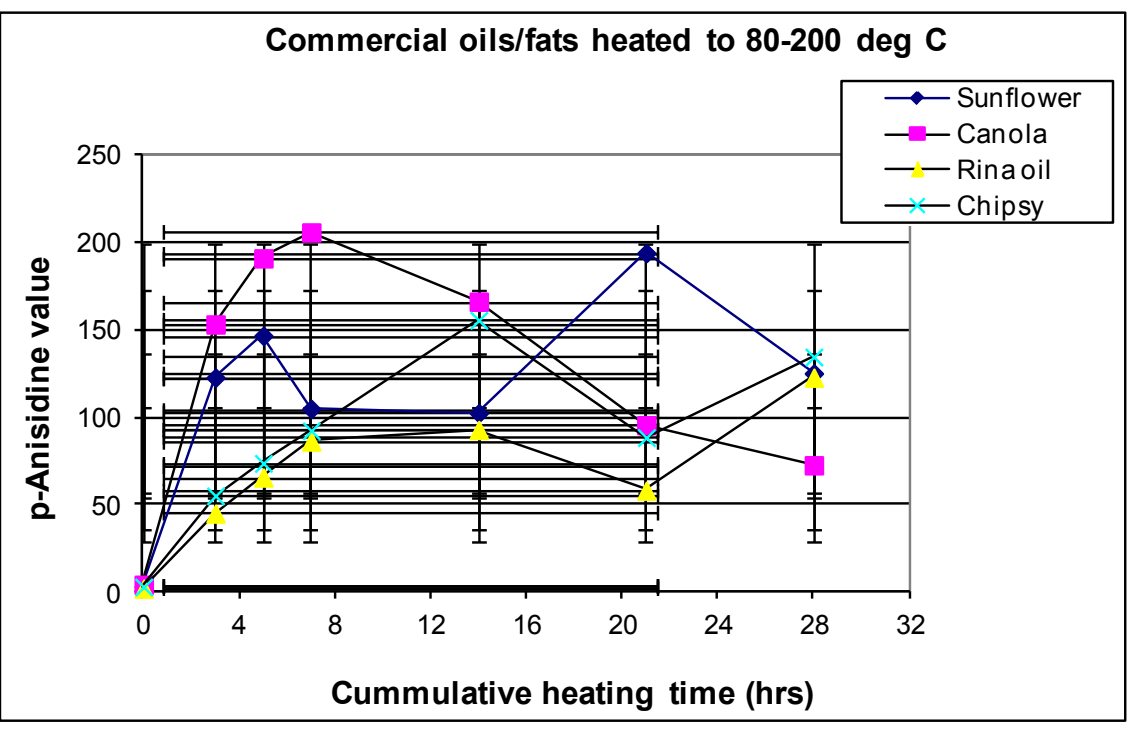

Figure 6. Changes in p-AV for plain oils heated to $180^{\circ} \mathrm{C}-200^{\circ} \mathrm{C}$.

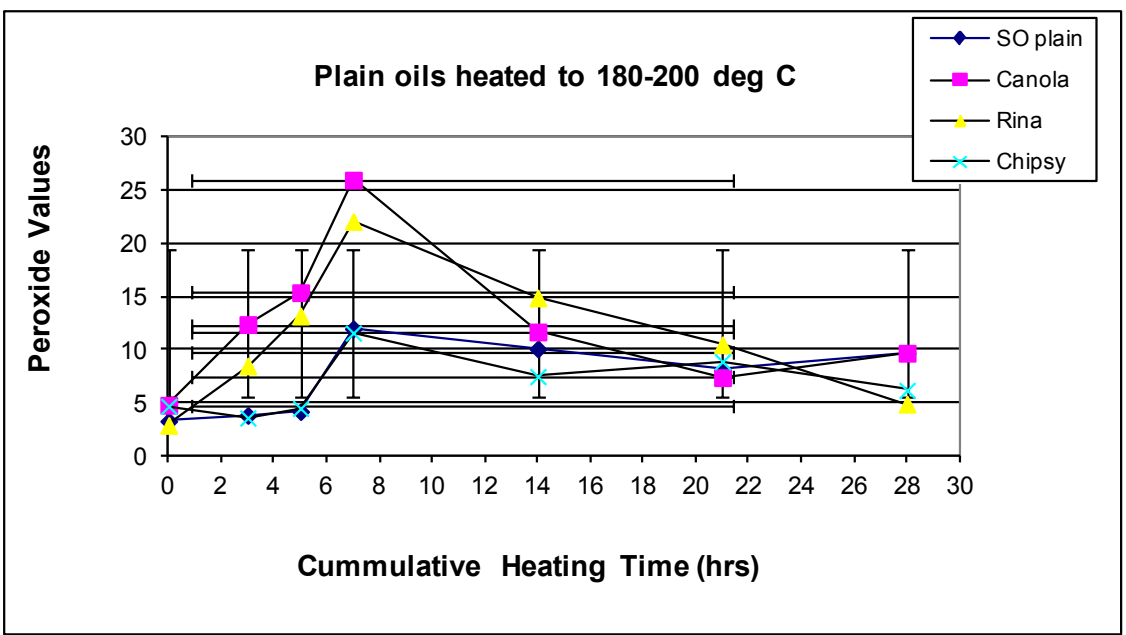

Figure 7. Changes in peroxide values for plain oils heated to $180^{\circ} \mathrm{C}-200^{\circ} \mathrm{C}$.

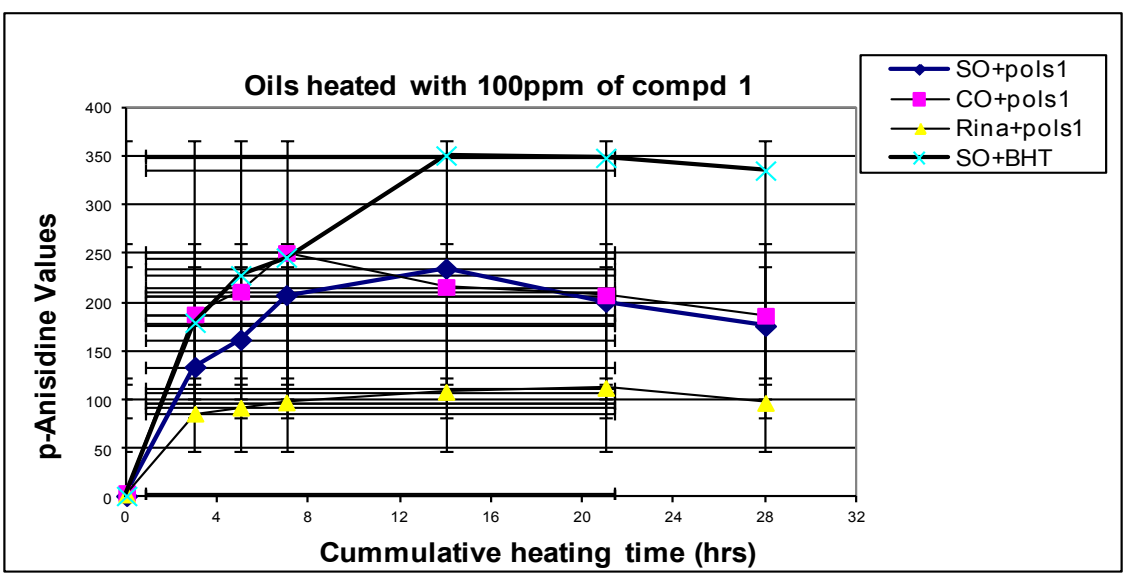

Figure 8. Changes in p-AV values for Oils heated with 100 ppm of 5-hydroxy-7methoxyflavanone $\underline{1}$. 


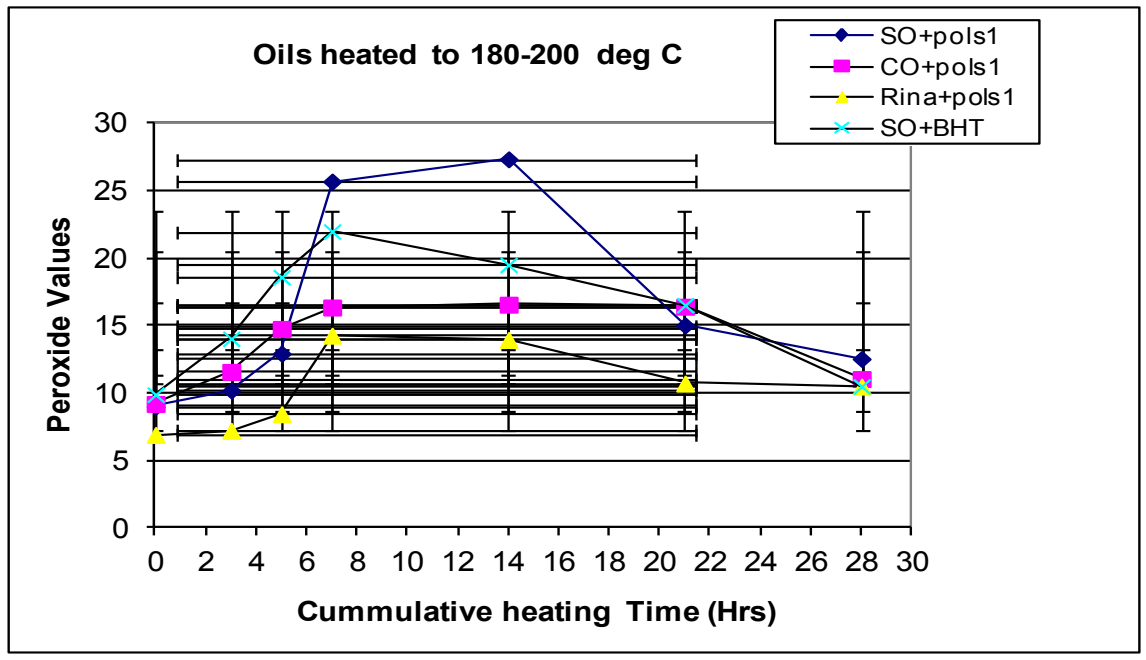

Figure 9. Changes in peroxide values for Oils heated with $100 \mathrm{ppm}$ of 5-hydroxy-7-methoxyflavanone $\underline{1}$.

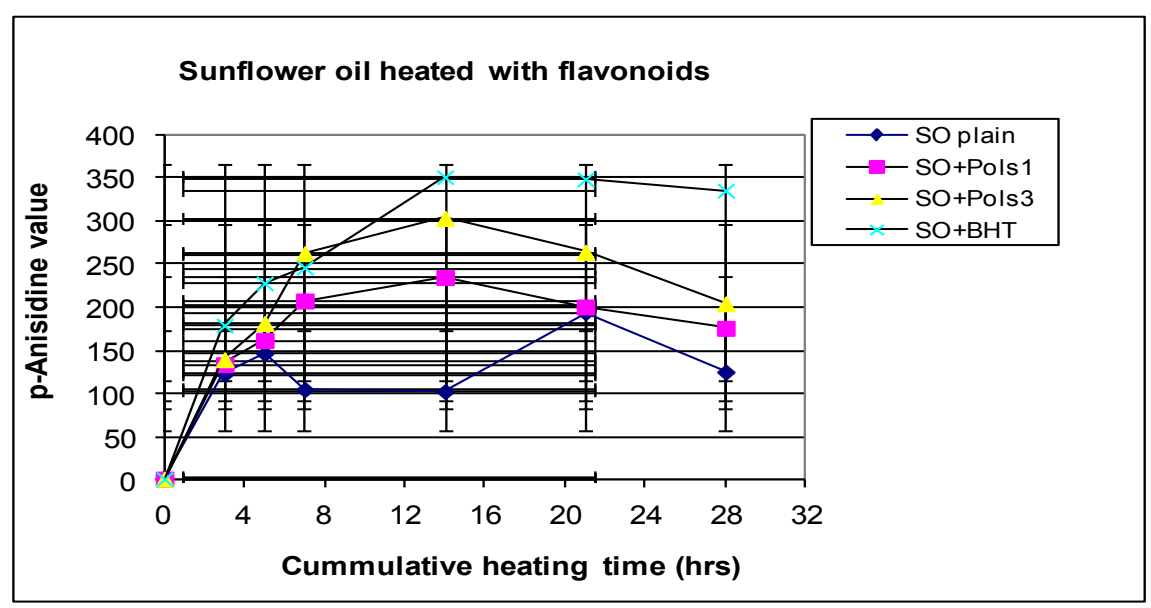

Figure 10. Changes in p-AV values for Sunflower oil heated with $100 \mathrm{ppm}$ of compounds 1 and 3.

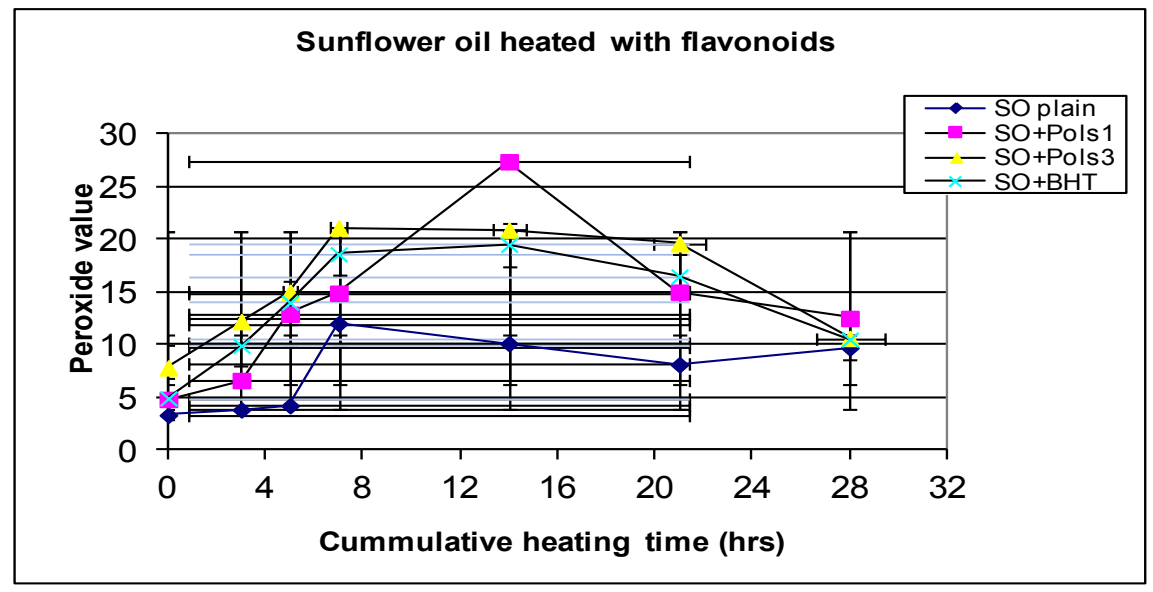

Figure 11. Changes in peroxide values for Sunflower oil heated with 100 ppm of compounds $\underline{1}$ and 3 . 


\section{Cytotoxicity Screening Tests}

Compounds $\underline{1}$ and $\underline{\mathbf{3}}$ had no significant cytotoxic effect against the $\mathrm{CHO}$ cell-line as observed in Table 1 and Figure 12 on dose-response curves.
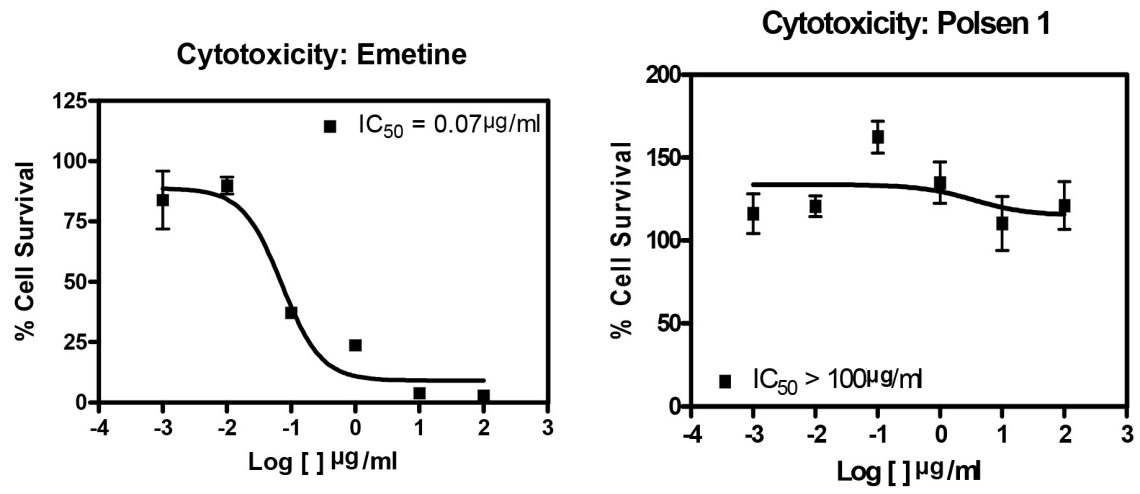

Cytotoxicity: Polsen 3

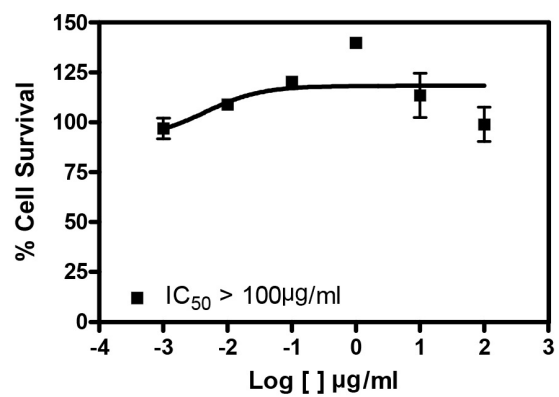

Figure 12. Dose-response curves of fractions using the CHO cell-line.

Table 1. $\mathrm{IC}_{50}$-values of fractions using the $\mathrm{CHO}$ cell-line.

\begin{tabular}{cc}
\hline Compound & IC50 $(\mu \mathrm{g} / \mathrm{ml})$ \\
\hline Polsen 1 (pols 1) & $>100$ \\
Polsen 3 (pols 1) & $>100$ \\
Emetine & 0.07 \\
\hline
\end{tabular}

The propensity of a flavonoid to inhibit free-radical mediated events is governed by its chemical structure. The number of substituent groups and their positions on the flavonoid structure can influence the radical-scavenging activity [27].

\section{Conclusion}

The present study indicate that 5-hydroxy-7-methoxyflavanone (pols $\underline{1}$ ) and 5-hydroxy-6,7-dimethoxyflavanone (pols $\underline{3}$ ) are effective anti-oxidants in retarding the formation of primary and secondary oxidation products during deep frying using vegetable oils. The two flavanones had no significant cytotoxic effect and are therefore potential food additives intended to serve as antioxidant principles in oil deep frying processes and in the formulation of animal feeds. The 
melting points of these flavanones are well above the melting point of BHT $\left(70^{\circ} \mathrm{C}\right)$.

\section{Acknowledgements}

The authors are grateful to the University of Kwa-Zulu Natal and Prof Dulcie Mullholand for support in laboratory space, chemicals and instruments.

\section{Conflicts of Interest}

The authors declare no conflicts of interest regarding the publication of this paper.

\section{References}

[1] Honold, P.J., Nouard, M.-L. and Jacobsen, C. (2016) Oxidative Stability during Storage of Fish Oil from Filleting By-Products of Rainbow Trout (Oncorhynchus mykiss) Is Largely Independent of the Processing and Production Temperature. European Journal of Lipid Science and Technology, 118, 967-973. https://doi.org/10.1002/ejlt.201500344

[2] Choe, E. and Min, D.B. (2006) Mechanisms and Factors for Edible Oil Oxidation. Comprehensive Reviews in Food Science and Food Safety, 5.

[3] Rade, D., et al. (1997) Frying of French Potatoes in Palm Oil and Vegetable Oil. Food Technology and Biotechnology, 35, 119-124

[4] Mahungu, S.M., Artz, W.E. and Perkins, E. (1999) Oxidation Products and Metabolic Processes. In: Boskou, D. and Elmadfa, I., Eds., Frying of Food, Technomic Publishing Company, Inc., Lancaster, 27.

[5] Srigley, C.T. and Rader, J.I. (2014) Content and Composition of Fatty Acids in Marine Oil Omega-3 Supplements. Journal of Agricultural and Food Chemistry, 62, 7268-7278. https://doi.org/10.1021/jf5016973

[6] Bartee, S.D., Kim, H.J. and Min, D.B. (2007) Effects of Antioxidants on the Oxidative Stability of Oils Containin Arachidonic, Docosapentaenoic and Docosahexaenoic Acids. Journal of the American Oil Chemists' Society, 84, 363-368. https://doi.org/10.1007/s11746-007-1046-4

[7] Anwar, F., Chatha, S.A.S. and Hussain, A.I. (2007) Assessment of Oxidative Deterioration of Soybean Oil at Ambient and Sunlight Storage. Grasas Y Aceites, 58, 390-395.

[8] German, J.B. (2002) Antioxidants. In: Larry Branen, A., Michael Davidson, P., Salminen, S. and Thorngate, J.H., Eds., Food Additives, Marcel Dekker, Inc., New York, 2nd Edition, 528.

[9] Wang, M.F., Li, J.G., Rangarajan, M., Shao, Y., La Voie, E.J., Huang, T.-C. and Ho, C.-T. (1998) Antioxidative Phenolic Compounds from Sage (Salvia officinalis). Journal of Agricultural and Food Chemistry, 46, 4869-4873. https://doi.org/10.1021/jf980614b

[10] Midiwo, J.O., Matasi, J.J., Wanjau, O.M., Mwangi, R.W., Waterman, P.G. and Wollenweber, E. (1990) Anti-Feedant Effects of Surface Accumulated Flavonoids of Polygonum senegalense. Bulletin of the Chemical Society of Ethiopia, 4, 123-127.

[11] Midiwo, J.O., Gikonyo, N.K., Wanjau, O.M., Matasi, J.J. and Waterman, P.G. (1992) Flavonoids of Polygonum senegalense (Meisn) Part II: More Surface and Internal Tissue Flavonoid Aglycones. Bulletin of the Chemical Society of Ethiopia, 6, 19-122. 
[12] Ogweno Midiwo, J., Owino, N.O. and Dagne, E. (1994) Flavonoids of Polygonum Senegalense Part III: Isolation of Dihydrochalcone Glucoside and Quercetin Glucosides. Bulletin of the Chemical Society of Ethiopia, 8, 79-84.

[13] Midiwo, J.O., Omoto, F.M., Yenesew, A., Akala, H.M., Wangui, J., Liyala, P., Wasunna, C. and Waters, N.C. (2007) The First 9-Hydroxyhomoisoflavanone, and Antiplasmodial Chalcones, from the Aerial Exudates of Polygonum senegalense. ARKIVOC 2007, ix, 21-27.

[14] Juma, B.F., Yenesewa, A., Midiwo, J.O. and Waterman, P.G. (2001) Flavones and Phenylpropenoids in the Surface Exudates of Psiadia punctulata. Phytochemistry, 57, 571-574. https://doi.org/10.1016/S0031-9422(01)00147-9

[15] Midiwo, J.O., Owuo, F.A.O., Juma, B.F. and Waterman, P.G. (1997) Diterpenes from the Leaf Exudates of Psiadia punctulata. Phytochemistry, 45, 117-120. https://doi.org/10.1016/S0031-9422(96)00812-6

[16] Rigotti, A. (2007) Absorption, Transport and Tissue Delivery of Vitamin E. Molecular Aspects of Medicine, 2, 423-436. https://doi.org/10.1016/j.mam.2007.01.002

[17] Alakali, J.S., Kucha, C.T. and Rabiu, I.A. (2015) Effect of Drying Temperature on the Nutritional Quality of Moringa oleifera Leaves. African Journal of Food Science, 9, 395-399. https://doi.org/10.5897/AJFS2014.1145

[18] Anelich, L.E.C.M., Kock, J.L.F., Roux, M.P., Botha, A., Benzuidenhout, S.M., Coetzee, D.J. and Venter, P. (2001) The Quality of Used Frying Fats in South Africa. South African Journal of Science, 97, 289-290.

[19] Midiwo, J.O., Gikonyo, N.K., Wanjau, O.M., Matasi, J.J. and Waterman, P.G. (1992) Flavonoids of Polygonum senegalense (Meisn) Part II: More Surface and Internal Tissue Flavonoid Aglycones. Bulletin of the Chemical Society of Ethiopia, 6, 19-122.

[20] Ogweno Midiwo, J., Yenesew, A., Juma, B.F., Derese, S., Ayoo, J.A., Aluoch, A.O. and Guchu, S. (2002) Bioactive Compounds from Some Kenyan Ethnomedicinal Plants: Myrsinaceae, Polygonaceae and Psiadia punctulata. Phytochemistry Reviews, 1, 311-323. https://doi.org/10.1023/A:1026029609500

[21] Paquot, C. and Hautfenne, A. (1987) Standard Methods for the Analysis of Oils, Fats and Derivatives. Blackwell Scientific Publications, London, 199-211.

[22] Zhang, B.-Y., Wang, H., Luo, X.-D., Du, Z.-Z., Wu, H.-F., Shen, J.-W. and Zhang, X.-F. (2012) Chemical Constituents of Euphorbia tangutica. Natural Product Research, 26, 2309-2315. https://doi.org/10.1080/14786419.2012.668686

[23] Mosmann, T. (1983) Rapid Colorimetric Assay for Cellular Growth and Survival: Application to Proliferation and Cytotoxicity Assays. Journal of Immunological Methods, 65, 55-63. https://www.ncbi.nlm.nih.gov/pubmed/6606682 https://doi.org/10.1016/0022-1759(83)90303-4

[24] Rubinstein, L.V., Shoemaker, R.H., Paull, K.D., Simon, R.M., Tosini, S., Skehan, P., Scudiero, D.A., Monks, A. and Boyd, M.R. (1990) Comparison of In Vitro Anticancer-Drug-Screening Data Generated with a Tetrazolium Assay against a Diverse Panel of Human Tumor Cell Lines. Journal of the National Cancer Institute, 82, 1113-1118.

[25] Jayaprakasam, B., Damu, A.G., Blond, A. and Bodo, B. (1999) Dihydroechioidinin, a Flavanone from Andrographis echioides. Phytochemistry, 52, 935-937. https://doi.org/10.1016/S0031-9422(99)00295-2

[26] Wu, T.-S., Kuoh, C.-S., Ho, S.-T., Yang, M.-S. and Lee, K.-K. (1981) Flavanone and Other Constituents from Onychium siliculosum. Phytochemistry, 20, 527-529. https://doi.org/10.1016/S0031-9422(00)84186-2

[27] Jeong, J.-M., Kang, S.-K., Lee, I.-H., Lee, J.-Y., Jung, H. and Choi, C.-H. (2007) An- 
tioxidant and Chemosensitizing Effects of Flavonoids with Hydroxy and/or Methoxy Groups and Structure-Activity Relationship. Journal of Pharmacy \& Pharmaceutical Sciences, 10, 537-546. http://www.cspsCanada.org

https://doi.org/10.18433/J3KW2Z 